\title{
Development and Characterization of Functional Ginger Powder Tablets
}

\author{
Manisha Kaushal*, Ranjan Kaushik, Devina Vaidya, Anil Gupta and Suman Dhiman \\ Department of Food Science \& Technology, Dr YS Parmar University of Horticulture \& \\ Forestry Nauni, Solan HP 173230, India \\ *Corresponding author
}

\section{A B S T R A C T}

K e y w o r d s
Ginger powder,
Tablets, carr
compressibility,
Hausner ratio,
Antioxidant activity
Article Info
Accepted:
20 December 2018
Available Online:
10 January 2019

\section{Introduction}

Ginger (Zingiber officinale Roscoe.) is a medicinal plant that has been widely used all over the world since antiquity, for a wide array of unrelated ailments including arthritis, cramps, rheumatism, sprains, sore throats, muscular aches, pains, constipation, vomiting, hypertension, indigestion, dementia, fever and infectious diseases (Ali et al., 2008; Platel and Srinivasan, 2000; Mustafa and Srivastava, 1990). It is one of the most important cash crop and principal spice of India. India being the largest producer and exporter of ginger to more than 50 countries, particularly to the Middle East, accounting for more than $70 \%$ of the world production (Pruthi, 1993). Ginger is valued due to the aromatic compounds giving a spicy, pungent and pleasant flavor (Bartley and Jacobs, 2000). Ginger bread, confectionery, ginger ale, curry powders, table sauces, pickling and certain soft drinks like cordials, ginger cocktail, carbonated drinks are some of the value added products of ginger; apart from the extraction of ginger oil, oleoresin, essences, tinctures etc. (Maizura et $a l ., 2011)$. The ginger powder can be utilized for development of different commercial products like cookies, candy, tea, tinctures, sodas, jam, beer and syrup (Govindarajan, 1982).

Depending upon the prevailing demand, ginger rhizome is harvested after six months 
of sowing for value addition and consumption due to its tenderness and presence of low fibre content. However, fresh ginger rhizome is perishable in nature and gets spoiled due to improper handling, growth of spoilage microorganism, action of naturally occurring enzymes, chemical reactions and structural changes during storage due to its high moisture content (Sagar and Kumar, 2009). Thus, dehydration of ginger is therefore a low cost method which can be implemented to reduce the post harvest losses with minimal changes in its physical, chemical and organoleptic properties (Kubra and Rao, 2012) due to reduced water activity. Further, in food industry, application of compaction is at developing stages, where compaction of powder into tablets is an excellent alternate for overcoming problems associated with postprocessing handling, packaging and storage of fruit and vegetable powders. Powder in tablet form becomes less hygroscopic due to reduction of surface area which facilitates in reducing packaging cost. The present study was therefore designed to develop and evaluate palatable formulation using ginger powder and other spices into an appetizing tablet form.

\section{Materials and Methods}

\section{Raw material}

The fresh ginger rhizome (cv. Himgiri) harvested at optimum maturity from the Department of Seed Science and Technology, UHF, Nauni, Solan Himachal Pradesh was used for powder preparation. The rhizomes after washing were peeled mechanically, sliced (approximately $2 \mathrm{~mm}$ thickness) and blanched in solution of 1.0 per cent citric acid (Dhiman, 2015) followed by drying in mechanical dehydrator at $55 \pm 2^{\circ} \mathrm{C}$ till the moisture content of slices reached below 10.00 cent (Jayshree et al., 2014). The dried slices were powdered into a pulverizer, sieved in $18 \mathrm{mesh} / \mathrm{inch}(1.04 \mathrm{~mm}) \mathrm{mesh}$ for product development. Other ingredients like common salt, black salt, mint, cumin powder, fennel powder, gulkand etc. for the formulation of tablets were procured from the local market. The fresh mint leaves were washed, dried in a vacuum drier and grounded into powder.

\section{Preparation of tablets}

The tablets were prepared by wet granulation method which involved binding of dry primary powder particles using a granulating fluid. The hypertonic sugar syrup and gulkand were used as binding agents and the TSS was maintained at $70^{\circ} \mathrm{B}$ each. The procedure involved mixing of all the ingredients listed in Table 1 except black salt and common salt with varying concentrations of ginger powder from $0,5,10,15,20,25,30 \mathrm{~g}$ and bound with gulkand as well as hypertonic sugar syrup to form the coherent mass. The mass was sieved through $18 \mathrm{mesh} / \mathrm{inch}(1.04 \mathrm{~mm})$ sieve and dried at $55 \pm 2^{\circ} \mathrm{C}$ for two hours, granulated followed by addition of black and common salt.

The said powder was compacted in Kambert Make 8 Station Mini Rotary Tablet Press Machine D tooling with a pressure of $9.8 \mathrm{kN}$ without pre-compression with 8 sets and 6 numbers dummy dies model KMP-D-8. The weight of each tablet was adjusted to $500 \mathrm{mg}$. The prepared tablets were packed in aluminium laminated pouches containing 6 numbers of tablets in each pack.

\section{Analysis}

Physico-chemical analysis of ginger powder and formulated tablets were conducted by using standard analytical procedures. Total soluble solid (TSS) content was determined by hand refractometer while, sugars were estimated by Lane and Eyon, 1923 method. Acidity was determined by titrating the 
aliquots against a standardized $0.1 \mathrm{~N} \mathrm{NaOH}$ solution to a pink end point using phenolphthalein as an indicator (Ranganna, 2009). Total phenols were extracted in $80 \%$ ethanol and were estimated using FolinCiocalteau reagent as per standard procedure (AOAC, 2004). The compaction properties like bulk density $(\mathrm{g} / \mathrm{ml})$ and tapped density $(\mathrm{g} / \mathrm{ml})$ of the ginger was estimated by the standard procedures. Further, flow property of ginger powder and tablet formulation was evaluated by using Carr compressibility (Carr, 1965) and Hausner Ratio (Hausner, 1967) with the following formula:

Carr compressibility $(\%)=$

Tapped density - Bulk density $\quad$ X 100

Tapped density

Hausner ratio $(\mathrm{HR})=$ Tapped density/ Bulk density

Angle of repose which is related to the density, surface area, shapes of the particles and the coefficient of friction of the material is calculated by fixed funnel method of Liu (2011) with the following formula.

Angle of repose $(\theta)=\operatorname{Tan}^{-1} \mathrm{~h} / \mathrm{r}$

where, $h=$ height of pile, $r$ = radius of base of pile

Water absorption index (WAI) was determined as described by Anderson (1969) where $1 \mathrm{~g}$ of the ginger powder was suspended in $12 \mathrm{~mL}$ of distilled water at ambient temperature in a tared centrifuge tube where the suspension was stirred in a vortex mixer for 1 minute, shacked for 30 minutes and then centrifuged in a Hermle centrifuge; model $\mathrm{Z} 383$ at $3500 \mathrm{rpm}$ for 10 minutes. The liquid supernatant was carefully transferred into a tared evaporating dish and dried at $110^{\circ} \mathrm{C}$ to constant weight. The weight of the remaining gel was taken as WAI and expressed in $\mathrm{g} / \mathrm{g}$.

$\mathrm{WAI}=$

Weight of wet solid remaining after centrifugation

Weight of initial dry sample

The amount of dried solids, recovered by evaporating the supernatant from the WAI was used for measuring per cent water solubility index (WSI).

Per cent $\mathrm{WSI}=$

Weight of dry solids after centrifugation

Weight of initial dry sample

Water activity was estimated by Computer Digital Water Activity Meter $\left(\mathrm{HW}_{3}\right.$ model, Rotronic International, Switzerland), where direct measurements were taken at room temperature. Standard cuvett was used in which products and powder were filled upto the brim and placed below the sensor of the water activity meter, which gave direct reading of water activity of the samples.

For determining the equilibrium relative humidity (ERH) $5 \mathrm{~g}$ of sample was spread evenly on tared petri dishes which were then placed inside the desiccators containing $\mathrm{H}_{2} \mathrm{SO}_{4}$ solutions of varying concentrations representing relative humidity levels ranging between $0-100$ per cent. The loss or gain in weight of sample was recorded at 24 hours till the samples attained the equilibrium. After equilibrium, data were plotted against relative humidity to determine ERH of given samples (Ranganna, 2009). Critical and danger points of different products were evaluated according to the weight equilibrium method of Wink (1946). 
For standardization of palatable formulation of tablets, the tablets were served for evaluation to a panel of 7-9 semi-trained judges for various quality attributes viz., colour, taste, flavour, body and overall acceptability on 9 point hedonic scale. The data pertaining to sensory evaluation were analyzed according to Randomized Block Design (RBD) as described by Mahony (1985) while, the data on chemical characteristics were analyzed statistically by following Completely Randomized Design (CRD) according to Cochran and Cox (1967).

\section{Results and Discussion}

\section{Physico-chemical properties of ginger powder}

The ginger powder under study had a moisture content of $7.05 \pm 0.62$ percent with water activity of $0.356 \pm 0.004$ and water absorption index and per cent water solubility index as $0.79 \pm 0.02$ and $14.00 \pm 0.01$ per cent respectively which was near to the values revealed by Phoungchandang and Sertwasana (2010) and Nakade et al., (2014). The per cent crude fat and per cent crude protein in ginger powder was calculated as $5.73 \pm 0.05$ and 6.63 \pm 0.61 respectively (Table 2 ). Further the presence of high phenols $(243.86 \pm 0.06$ $\mathrm{mg} / 100 \mathrm{~g}$ ) and appreciable antioxidant activity $(83.73 \pm 0.04 \%)$ highlighted its nutritional significance. A high amount of ash content $(5.33 \pm 0.03 \%)$ further emphasized its rich mineral composition.

\section{Flow properties of ginger powder}

Data pertaining to the flow properties of ginger powder presented in Table 3 elucidate that the powder had a Carr compressibility of 12.28 per cent and Hausner ratio of 1.14 with a bulk density and tapped density as $0.50 \mathrm{~g} / \mathrm{ml}$ and $0.57 \mathrm{~g} / \mathrm{ml}$ respectively. The angle of repose calculated by fixed funnel method was found $27^{\circ}$ and categorized in excellent flow able powder according to the classification given by US Pharmacopeia (2016). Thus, the excellent flow behavior of ginger powder predicted from carr compressibility, hausner ratio and angle of repose indicated that the powder was well suited to be compressed into tablets.

Standardization of formulation for the preparation of ginger powder based tablets

The tablets prepared by using different concentrations of ginger powder from $(5,10,15,20,25,30 \mathrm{~g})$ with a pre-standardized recipe (Table 1) and varying binding agents (gulkand and sugar syrup) were subjected to sensory evaluation to screen the most palatable formulation. The results showed that significantly higher scores for colour, texture, aroma, taste and overall acceptability were scored by treatment combination $25 \mathrm{~g}$ ginger powder in recipe $\mathrm{R}$ and gulkand as binding agent $\left(\mathrm{T}_{6} \mathrm{RS}_{2}\right)$. Lower concentrations of ginger powder in the formulation was not liked by the panelists due to less preferable taste while high amount of ginger powder in the formulation was rejected due to increased pungency of ginger powder in the tablet. The type and amount of binders decisively influences the characteristics of the tablets prepared by wet granulation procedure (Tavakoli et al., 2008). Thus, a formulation having $25 \mathrm{~g}$ ginger powder in recipe $\mathrm{R}$ with gulkand as binding agent was optimized for further experimentation.

\section{Pre-compression flow properties of tablet formulation (granules)}

After screening the concentration of ginger with the prestandarized recipe and gulkand as binding agent $\left(\mathrm{T}_{5} \mathrm{RS}_{2}\right)$, the granular formulation was subjected to analysis of various flow characteristics before compaction into tablets by wet granulation so 
as to study its suitability for preparation of tablets. The formulation had Carr compressibility of 18.72 per cent and Hausner ratio 1.23 calculated from bulk density $(0.625 \mathrm{~g} / \mathrm{ml})$ and tapped density $(0.761 \mathrm{~g} / \mathrm{ml})$. Thus, according to US Pharmacopeia (2016) these characteristics categorize the granules under the category of fair while the angle of repose categorized the granules as good with values of $32^{\circ}$ thus found suitable for the preparation of good quality tablets.

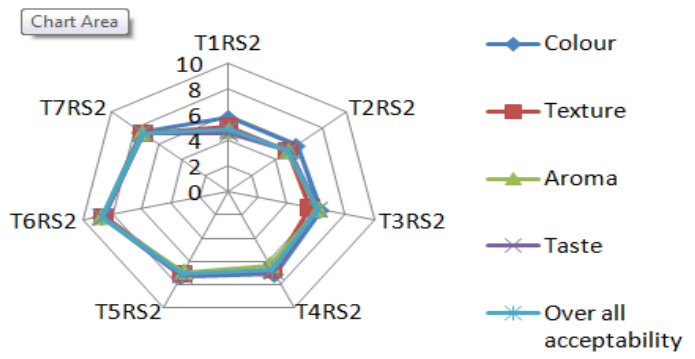

Ginger tablets (gulkand- S2)

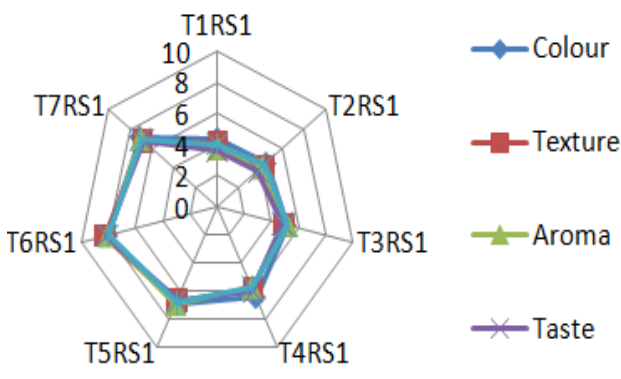

Ginger tablets (sugar syrup-S1)

T1-Control (without ginger); T2-5g; T3-10g; T4-15g; T5-20g; T6-25g; T7-30g ginger powder; R- recipe

Table.1 Ingredients (R) for the preparation of ginger appetizing tablets

\begin{tabular}{|l|c|}
\hline \multicolumn{1}{|c|}{ Ingredients } & Weight $(\mathrm{g})$ \\
\hline Sugar powder & 30 \\
\hline Anardana powder & 25 \\
\hline Mango powder (Amchoor) & 5 \\
\hline Common Salt & 2 \\
\hline Black salt & 2 \\
\hline Fennel powder & 2 \\
\hline Cumin powder & 2 \\
\hline Mint powder & 2 \\
\hline Gulkand/ Hypertonic sugar syrup & 18 \\
\hline
\end{tabular}


Table.2 Physico-chemical characteristics of ginger powder

\begin{tabular}{|c|l|c|}
\hline S. No. & \multicolumn{1}{|c|}{ Parameters } & $\begin{array}{c}\text { Ginger Powder } \\
\text { Mean } \pm \text { SD }\end{array}$ \\
\hline $\mathbf{1}$ & Moisture content $(\%)$ & $7.05 \pm 0.62$ \\
\hline $\mathbf{2}$ & Water activity $\left(\mathrm{a}_{\mathrm{w}}\right)$ & $0.356 \pm 0.004$ \\
\hline $\mathbf{3}$ & Water absorption index & $0.79 \pm 0.02$ \\
\hline $\mathbf{4}$ & Per cent water solubility index & $14.00 \pm 0.01$ \\
\hline $\mathbf{5 .}$ & Total phenols $(\mathrm{mg} / 100 \mathrm{~g})$ & $243.86 \pm 0.06$ \\
\hline $\mathbf{6 .}$ & Antioxidant activity $(\%)$ & $83.73 \pm 0.04$ \\
\hline $\mathbf{7 .}$ & Crude fat $(\%)$ & $5.73 \pm 0.05$ \\
\hline $\mathbf{8 .}$ & Crude protein $(\%)$ & $6.63 \pm 0.61$ \\
\hline $\mathbf{9 .}$ & Crude fibre $(\%)$ & $10.11 \pm 0.03$ \\
\hline $\mathbf{1 0 .}$ & Ash content $(\%)$ & $5.33 \pm 0.03$ \\
\hline
\end{tabular}

Table.3 Physical evaluation parameters of ginger powder

\begin{tabular}{|c|l|c|}
\hline S. No. & \multicolumn{1}{|c|}{ Parameters } & Ginger Powder \\
\hline $\mathbf{1}$ & Bulk density $(\mathrm{g} / \mathrm{ml})$ & 0.50 \\
\hline $\mathbf{2}$ & Tapped density $(\mathrm{g} / \mathrm{ml})$ & 0.57 \\
\hline $\mathbf{3}$ & Angle of repose & $27^{\circ}($ Excellent $)$ \\
\hline $\mathbf{4}$ & Carr compressibility $(\%)$ & $12.28(\mathrm{Good})$ \\
\hline $\mathbf{5}$ & Hausner ratio & $1.14(\mathrm{Good})$ \\
\hline
\end{tabular}

Table.4 Nutritional characteristics of ginger tablets

\begin{tabular}{|l|l|l|}
\hline $\begin{array}{l}\text { Sr. } \\
\text { No. }\end{array}$ & \multicolumn{1}{|c|}{ Parameter } & Ginger tablets \\
\hline $\mathbf{1}$ & Moisture content $(\%)$ & $1.97 \pm 0.27$ \\
\hline $\mathbf{2}$ & Water activity $\left(\mathrm{a}_{\mathrm{w}}\right)$ & $0.373 \pm 0.003$ \\
\hline $\mathbf{3}$ & Titratable acidity $(\%$ citric acid) & $0.32 \pm 0.02$ \\
\hline $\mathbf{4}$ & Total phenols $(\mathrm{mg} / 100 \mathrm{~g})$ & $167.26 \pm 0.09$ \\
\hline $\mathbf{5}$ & Antioxidant activity $(\%)$ & $84.30 \pm 0.11$ \\
\hline $\mathbf{6}$ & Crude fibre $(\%)$ & $6.53 \pm 0.07$ \\
\hline $\mathbf{7}$ & Ash content $(\%)$ & $6.72 \pm 0.04$ \\
\hline
\end{tabular}


Physico-chemical characteristics of ginger powder based tablets

On the basis organoleptic quality and compaction properties, 25.0 percent ginger powder in recipe $\mathrm{R}$ and gulkand $\left(70^{\circ} \mathrm{B}\right)$ as binding agent was standardized and was subjected to physiochemical characteristics. The data in the Table 4 elucidate that the standardized tablets had a water activity of $0.373 \pm 0.003$ with a moisture content of $1.97 \pm 0.27$ and a titratable acidity of $0.32 \pm 0.02$ per cent citric acid. Nutritionally, the tablet contained a huge amount of total phenols $(167.26 \pm 0.09 \mathrm{mg} / 100 \mathrm{~g})$, antioxidant activity $(84.30 \pm 0.11 \%)$, crude fibre $(6.53 \pm 0.07 \%)$ and ash $(6.72 \pm 0.04 \%)$ content thereby highlighting the significance of addition of ginger in the appetizing tablets.

The present investigation concludes that the ginger powder possessing appreciable nutritional properties and can successfully be utilized for the preparation of tablets. The ginger powder supplemented tablets with high total phenols and antioxidant activity highlighting the significance of addition of ginger in the appetizing tablets. The technology helps in developing nutritionally rich novel product for the market, thereby generating new income source among farmers which can further boost entrepreneurship development.

\section{References}

Ali BH, Blunden G, Tanira MO and Nemmar A. 2008. Some phytochemical, pharmacological and toxicological properties of ginger (Zingiber officinale Roscoe): a review of recent research. Food and Chemical Toxicology 26: 409-20.

Anderson RA. 1969. Water absorption and solubility and amylograph characteristics of roll cooked small grain products. Cereal Chemistry 59:265-69.

AOAC. 2004. Official Methods of Analysis. Association of Official Analytical Chemists. $17^{\text {th }}$ ed. Washinton, DC

Bartley J and Jacobs A. 2000. Effects of drying on flavour compounds in Australian-grown ginger (Zingiber officinale). Journal of Food Science and Agriculture 80: 209-15.

Carr RL. 1965. Evaluating flow properties of solids. Chemical Engineering Journal. 72:69-72

Cochran WG, Cox CM. 1967. Experimental Designs. John Wiley and Sons, Inc., New York. p 1874

Dhiman A. 2015. Development and evaluation of novel products from ginger (Zingiber officinale). M.Sc. Thesis, Department of Food Science and Technology, Dr YS Parmar University of Horticulture and Forestry, Solan, pp 115.

Govindarajan VS. 1982. Ginger: Chemistry, technology and quality evaluation. Critical Reviews Food Science and Nutrition 7:1-96.

Hausner HH. 1967. Friction conditions in a mass of metal powder. International Journal of Powder Metallurgy. 3:7-13

Jayashree E, Kandiannan K, Prasath D, Rashid P, Sasikumar B, Kumar S C M, Srinivasan V, Susheela B R and Thankamani C K. 2014. Ginger (Extension Pamphlet). ICAR- Indian Institute of spice Research, Kozhikode, Kerla. pp. 1-10.

Kubra IR, Rao LJM. 2012. Effect of microwave drying on the phytochemical composition of volatiles of ginger. International Journal of Food Science and Technology 47: 53-60

Liu Z. 2011. Measuring the Angle of Repose of Granular Systems Using Hollow Cylinders. M.S Thesis. University of Pittsburgh, http://d- 
scholarship.pitt.edu/6401/.

Mahony, MO.1985. Sensory Evaluation of Food: Statistical Methods and Procedures. Marcel Dekker INC. New York.

Maizura M, Aminath A and Wan A W M. 2011. Total phenolic content and antioxidant activity of kesum (Polygonum minus), ginger (Zingiber officinale) and Turmeric (Curcuma longa) extract. International Food Research Journal. 18: 529-534

Mustafa, T, Srivastava, KC. 1990. Ginger (Zingiber officinale) in migraine headachs. J Ethenopharmacology., 29: 267-273.

Nakade VP, Shakya BR and Pawar YR. 2014. Studies on drying characteristics of ginger and rheological properties of superfine ginger powder. International Journal of Research in Engineering and Advanced Technology 2:1-8.

US Pharmacopeia. 2016. National Formulary USP 23/NF 18 United States Pharmacopeial Convention, Inc., Rockville, MD

Phoungchandang S, Sertwasana A (2010) Spray-drying of ginger juice and physico-chemical properties of ginger powders. Science Asia 36:40-45

Platel, K., Srinivasan, K., 2000. Influence of dietary spices and their active principles on pancreatic digestive enzymes in albino rats. Nahrung 1:42-46.

Pruthi J S. 1993. Major spices of India; crop management post harvest technology. New Delhi, Indian Council of Agricultural Research. pp. 244-288.

Ranganna S. 2009. Handbook of Analysis and Quality Control of Fruit and Vegetable Products. 4th edn. Tata McGraw Hill, New Delhi, pp. 1112.

Sagar VR and Kumar R. 2009. Effect of packaging and storage on the quality of ginger, onion and garlic (GOG) mix powder. Indian Journal of Horticulture. 66: 367-373.

Tavakoli N, Teimouri R, Hamishehkar H. 2008. Characterization and evaluation of okra gum as a tablet binder. Jundushapur Journal of Natural Pharmaceutical Products 3:33-38.

Lane J H and Eynon L. 1923.Determination of reducing sugars by Fehling's solution with methylene blue as an indicator. Journal of Chemistry Industry. 42: 32

Wink WA. 1946. Equilibrium relative humidity studies and determination of packaging material for apple cheese. Industrial Engineering Chemistry and Analytical Edition 27:59-61.

\section{How to cite this article:}

Manisha Kaushal, Ranjan Kaushik, Devina Vaidya, Anil Gupta and Suman Dhiman. 2019. Development and Characterization of Functional Ginger Powder Tablets. Int.J.Curr.Microbiol.App.Sci. 8(01): 2918-2925. doi: https://doi.org/10.20546/ijcmas.2019.801.310 